\title{
Correction to: Introduction to Comparative Political Culture
}

\section{Correction to: \\ D. Tong, Introduction to Comparative Political Culture, https://doi.org/10.1007/978-981-13-1574-9}

The sponsorship statement "Sponsored by Chinese Fund for the Humanities and Social Sciences (本书获中华社会科学基金资助)” in the copyright page (iv) of Frontmatter, which was inadvertently omitted in the original version, has now been included. The erratum book has been updated with the change.

The updated online version of this book can be found at https://doi.org/10.1007/978-981-13-1574-9

(C) Higher Education Press and Springer Nature Singapore Pte Ltd. 2019 